\title{
DEVELOPING LEADERS OR DEVELOPING LEADERSHIP? THE ACADEMY OF CHIEF EXECUTIVES' PROGRAMMES IN THE NORTH - EAST OF ENGLAND
}

PAUL ILES and DAVID PREECE

Published in Leadership, Vol. 2, No. 3, 2006, pp.317-340

Paul Iles, Professor of Strategic Human Resource Management

The Business School, University of Teesside, Borough Rd Middlesbrough TS1 3BA UK

Tel 01642342800

Fax 01642342925

Email paul.iles@tees.ac.uk

David Preece, Professor of Technology Management \& Organization Studies

The Business School, University of Teesside, Borough Road, Middlesbrough, TS1 3BA, UK(corresponding author)

Tel 01642342919

Fax 01642342925

Email d.preece@tees.ac.uk 
Paul Iles is the Professor of Strategic HRM, Head of the Centre for Leadership and Organisational Change and MBA Programme Leader at Teesside Business School, University of Teesside. A Chartered Fellow of the CIPD, Associate Fellow of the British Psychological Society, and a Chartered Psychologist, he was previously the Littlewoods' Professor of Human Resource Development at Liverpool Business School, Liverpool John Moores University, and a Senior Lecturer at the Open University Business School. He is the co-editor of the Journal of Organisational Transformation and Social Change, and assistant editor of the Journal of Technology Management in China.

David Preece is Professor of Technology Management and Organization Studies and DBA Programme Leader at Teesside Business School, University of Teesside. He has previously worked at the Universities of Portsmouth, Coventry, Leeds and Bradford. He is Editor of the Routledge Research Monograph Series Work, Technology and Organizations. He has published widely through refereed journal articles and books, and his most recent book is Technological Change and Organizational Action, Routledge, 2003 (co-edited with Juha Laurila). 


\begin{abstract}
The paper distinguishes between leaders and leadership on the one hand, and leader and leadership development on the other. It then explores a particular mode of leadership development, based upon membership of the UK Academy of Chief Executives (ACE). ). Semi-structured interviews, documentary analysis, and participant observation were used to study the experiences and obtain the views of members of the North East England branch of the ACE. It is argued that leadership development has often been equated with leader development, with the resulting focus upon the individual, as against attending to the social, political, collective and other contexts of action and meaning. Social capital theory, following Day (2000) is drawn upon in order to help conceptualise and apply leadership development in context, where the emphasis is upon understanding and building relationships and networks, coordinating activities, and developing commitments.
\end{abstract}

\title{
KEYWORDS
}

Leaders, leadership, leader development, leadership development, Academy of Chief Executives. 
DEVELOPING LEADERS OR DEVELOPING LEADERSHIP? THE

ACADEMY OF CHIEF EXECUTIVES PROGRAMMES IN THE NORTH -

\section{EAST OF ENGLAND}

\section{INTRODUCTION}

On the basis of a critical review, we argue that leadership development as theorized and as practised, has too often been equated with leader development. This has resulted in a focus upon the individual, as against attending to the social, political, collective and other contexts of action and meaning. The upshot of this has been that there has been a misallocation of resources in the attempt to develop leadership capacity.

We distinguish between leaders and leadership on the one hand, and leader development and leadership development on the other, and outline and review these literatures. It is noted that there is a dearth of critical studies of approaches to leadership development despite the increasing interest shown in the phenomena in recent years. Leadership development is about the development of leadership processes in context, as well as the development of leaders as individuals. Leader development can be seen as involving the enhancement of human capital, whilst leadership development is about the creation of social capital. Thus, the latter involves extending the collective ability of people to effectively undertake leadership roles and processes, and is centrally about helping them to understand how to join and build social networks, develop commitments, and access resources. These 'leadership roles' come with and without formal authority. It is thus necessary to understand and act on the interactions between the 'leader' and the social, economic and political environment, with leadership being an emergent property of this interaction. 
In a later section of the paper, we explore the issues outlined above through a detailed consideration of a particular mode of leadership development, that which is derived from membership of the UK Academy of Chief Executives (ACE). Social capital theory, following Day (2000), is drawn upon in order to aid the conceptualisation and application of leadership development in context, where the emphasis is upon such matters as understanding and building relationships and networks, coordinating activities, and developing commitments.

The paper is organised in the following sections: (i) a review of the literature on leaders and leadership; (ii) a review of the leader development and leadership development literature; (iii) an overview of the research project and the Academy for Chief Executives; (iv) a methodological note; (v) the presentation and analysis of our findings; (vi) a concluding discussion.

\section{LEADERS AND LEADERSHIP}

Early approaches to the study of leadership focussed either on leader ' traits' (failing to find much consistency across sectors and organisations) or, after WW11, on leadership 'styles'. However, in the 1980s the focus was very much on 'management' rather than 'leadership', with an emphasis on management development, management competencies, and managerial assessment. The $21^{\text {st }}$ Century however is a time of renewed academic and political interest in leadership (see, eg, Grint, 2005; Storey, 2004). 'Leadership' is no longer the 'politically incorrect' word it once was, but the subject of a plethora of books, articles and conference papers, as well as government and corporate initiatives of various kinds. Whereas in the 1980s and early 1990s there was sustained interest in management, 
now there is the suggestion that management is not enough- we need leaders too, almost to the point where mere 'management' has become a negative word (eg Bennis and Nanus, 1985).

There has also been a shift back in leadership theorising in some senses to the orthodoxy of the ' one best way' of leading that was current in the 1960s. Whether described by the 1950s Ohio State or Michigan studies in terms of structure and consideration, or a concern for task and a concern for people, or by Blake and Mouton (1985) in terms of a the team leader's concern for both people and production, it appeared to many researchers that the most effective leader was one attentive to both the task and socio-emotional/ relationship dimensions of leadership.

However, it has become clear that such a model of leadership is decontextualised and individualistic; most research in the area was conducted by psychologists on small groups and the behaviour (self- reported by the leader or reported by team members) of team- leaders or supervisors, rather than leaders of large organisations. In addition, the main measures of team performance employed were attitudinal or perceptual. Other theorists have tried to develop more contingent theories of leadership, especially 'situational' theories of leadership which have stressed the need to adapt the leader's style to the demands of the situation. However, most also focussed on the leader of the small group and the situation of his or her 'followers', seen in terms of their maturity or the leaders' position power or relationship with their followers. (eg Hersey and Blanchard, 1982; Fiedler, 1967 and 1996).

In contrast, the 1990s saw a concern with 'creating corporate culture', with organisational symbolism and with the need to bring about ' transformational leadership' in large organisations facing new global challenges. This led to a renewed 
interest in earlier, more political and sociological accounts of leadership, such as the work of Burns (1978) and of Weber (1978) on charisma.

One widely influential view compares management with leadership, often to the latter's favour: whereas managers are concerned with today, with delivery, targets, efficiency, utilisation, and authority, focussing on internal organisational issues, on control and on doing things right, leaders are held to be oriented to tomorrow, to development, to direction, to purpose and vision, and to innovation. They focus on external issues, facilitation, empowerment and doing the right thing. Kotter (1990) has argued in contrast that organisations, needing to promote both stability and change, require both leaders and managers. Leading change is the focus of leaders, who need to increase urgency, build a guiding team, get the vision right, communicate for buy-in, empower action, create short- term wins, not let up, and make change stick. In a recent interview (Manocha 2004) he notes, however, that many organisations still fail to acknowledge the difference between leadership and management.

A very influential model of leadership comes from the work of Bass (1985, 1990), who compared ' transactional' leaders, exercising contingent reward and management by exception, with ' transformational' leaders, exercising idealised influence and inspirational motivation in a ' charismatic- inspirational' style. Such leaders stimulate organisational members intellectually and give them individualised consideration. In empirical studies, transformational leadership was more highly correlated with the exertion of extra effort, satisfaction with the leader, and perceptions of leader effectiveness. It is usually measured by the 360 degree Multifactor Leadership Questionnaire (MLQ) instrument (Bass and Avolio, 1993). 
In most studies, no practising leaders are actually observed, and the specificity and generalisability of the instrument has often been questioned (eg van der Weide and Wilderom, 2001), as well as the confusing combination of the emotional 'charisma' construct with the rational 'vision' construct ( Khatri, Harvey and Tirimizi, 2001). Students of 'managerial behaviour' have often criticised 'leadership' researchers for focussing on what leaders 'should' do, not what they actually do (as in the prescriptive model of Kotter, 1990).

Frameworks such as those above carry with them the danger of once again proposing a 'one best way' of leadership and of de-contextualising it, in particular by seeing it in terms of a set of individual leadership 'competencies'. What is more, as Alimo- Metcalfe and Alban-Metcalfe (2001) have suggested, such a model is rooted in a strong U.S., male and private- sector view of the 'heroic leader'. Particularly postEnron, such a model is open to serious challenge.

In their study of male and female British public- sector health and local government managers during the development of a new transformational leadership questionnaire, the TLQ, factor analysis revealed nine key factors related to how UK public sector managers perceived the ideal ' near' transformational leader (in contrast to most US studies of 'far' leaders, eg Chief Executives): a genuine concern for others, political sensitivity and skills, decisiveness, determination and self-confidence, integrity, trustworthiness, honesty and openness, empowering and developing potential, inspirational networking and promotion, accessibility and approachability, clarifying boundaries and involving others, and encouraging strategic thinking. A concern in the UK public sector with issues of ethics, integrity and external networks, as well as with organisational and inter- organisational politics, has been found in studies of leadership in the public services in other countries (eg Ehrich et al, 2005). 
More recent UK literature on transformational leadership has tried to build on the distinction between the two leadership styles by exploring a wider range of organisational contexts in which leaders operate. An emerging argument (eg Higgs, 2003 ) is that effective leaders are distinguished from less effective ones through the exercise of a relatively small number of 'competence areas'. The way these are exercised is a function of the underlying personality of the leader; the areas of effectiveness need to be exercised in a way which is congruent with leader personality (see, eg, Goffee and Jones, 2000; Hogan and Hogan, 2001). The model identifies the required leadership competence areas as envisioning, engaging, enabling, inquiring and developing. The personal characteristics of the leader are seen as authenticity, integrity, will, self- belief, and self- awareness.

Recent work has stressed the importance of 'emotional intelligence' to leadership, especially transformational leadership. Salovey and Mayer (1990) have argued that people vary in their capacity to process emotional information/relate to wider cognition, and Goleman (1996) took this further by associating ability in this area, called 'emotional intelligence' or EI, with leadership and business success. 'Successful people' were said to be higher in EI and better able to perceive, understand, and regulate their emotions.

Changes in the way we now think about leadership have opened up connections with the world of 'Futures Studies'. Boydell et al (2004), for example, argue that instead of focussing on the personal qualities of leaders, we need to focus on the leadership challenges faced by communities, societies and organisations in a more collective way. They conceptualise leadership situations in terms of their challenges, their contexts and the characteristics of everyone involved, including those designated as 'leaders'. Thus the focus is on developing leadership rather than 
leaders (see also Grint, 2005), and on 'leaderful' organisations and 'distributed' leadership, which has some affinity with the 'connected' and 'relational' leadership models discussed earlier.

Alvesson and Svenningsson (2003: 961) point out that normative leadership research sees 'the leader as consistent essence, a centred subject with a particular orientation': however, leaders are not 'the autonomous, self-determining individual with a secure unitary identity (at) the centre of the social universe (Alvesson and Deetz, 2000: 98).

A development of this approach is to take a social constructivist perspective on leadership (eg Sjostrand and Tyrstrup, 2001). Another is to move away from the 'individualistic' focus of much leadership theory by focussing on 'shared' leadership. For example, Gibb (1969) distinguished ‘focused' from 'distributed' leadership, contrasting the focus on sole leaders, usually 'heroic', 'transformational' and 'charismatic' CEOs with shared, dispersed or 'distributed' leadership, where reciprocal influence processes operate and team structures and empowerment are seen to grow in importance. Yukl (1999: 293) suggests that 'an alternative perspective would be to describe leadership as a shared process of enhancing the collective and individual capacity of people to accomplish their work roles effectively...the leadership actions of any individual leader are much less important than the collective leadership provided by members of the organisation'. For House and Adtja (1997: 457) 'leadership involves collaborative relationships that lead to collective action': distributed leadership can be delegated, co-leadership, or peer leadership. For Gronn (2002) distributed leadership can be dispersed or 'numerical', or conjoint and 'concertive': the first suggests that all organisational members can be leaders at some time, the second results from conjoint, synchronised agency and actions, either 
through spontaneous collaboration, intuitive working relationships, or as institutionalised practice, as in formal leadership teams. Distributed leadership is characterised by interdependence and the complementary overlapping of responsibilities, and co-ordination and the management of interdependencies. Examples include Inglis and Sarros (2003) and their study of an Australian voluntary nonprofit organisation, where leadership was distributed as institutionalised, concerted and complementary, interdependent action between the Executive Officer, President and Program Manager. Doos and Wilhemson (2003) studied shared leadership in four Swedish organisations- the national football team, a product development company, a management consulting firm and a communications company. In their analysis, leadership was seen in terms of 'co-leadership', as a specific form of shared leadership where the two leaders worked side by side, not in tandem with each other, with each exercising equal responsibility and influence. This process was seen as contributing to sustainability and enhanced competence, and Doos and Wilhemson (2003:1) make the point that 'learning, grounded in interaction and communication' is key to its success, with the actors as active constructors of knowledge. We can therefore see leaders as members of a community of practice (Drath and Palus, 1994; Horner, 1997; Wenger, 1998).

\section{LEADER DEVELOPMENT AND LEADERSHIP DEVELOPMENT}

The central argument of this paper is that 'leadership development', whilst increasingly fashionable, has tended to be equated with 'leader development', focussing on the training and development of the individual competencies, skills and attributes of the leader. The distinction between leaders and leadership (Grint, 2005; Boydell et al, 2004) can also be applied to leadership development. 
With respect to leadership development initiatives per se, there is a lack of empirical research on the effectiveness of different approaches to leadership development, whilst at the same time there is a growing interest in new approaches to leadership development (see, eg Antonacopoulou and Bento, 2004). There is a plethora of approaches to management development (see, eg, Thomson et al, 2001), from the formal (MBA, management training courses) through development centres and outdoor development to the informal (on-the-job learning, coaching, mentoring). Much management development involves the acquisition of 'specific types of knowledge, skills, and abilities to enhance task performance in management roles... the application of proven solutions to known problems, which gives it mainly a training orientation' (Day, 2000: 582) How appropriate these approaches are to leadership training and development is open to question, as little research and evaluation has taken place.

What are commonly called 'leadership development' programmes are often in fact 'leader development' programmes, often involving a mixture of competency models, psychometric assessment of personality, emotional intelligence, team management profile, 360 degree feedback, communication skills training, coaching, mentoring, motivational speeches and outdoor development. For example, IDS (2003) reviewed 'leadership' development programmes in five UK public and private organisations. Noting that 'it is now a fairly safe bet that most organisations...have come to regard the quality of their leadership as a significant business issue' and that 'as all our companies recognise, is that management and leadership roles are quite different and demand different competencies' (IDS 2003:1), they show how developing a leadership 'competency framework' was central to each of the five case studies. Change orientation, drive for excellence, impact and influence, strategic 
thinking and customer focus all featured strongly, with 'emotional intelligence' emerging rapidly, alongside self-awareness and contrasting leadership styles, especially in the public sector. The programmes were often developed in partnership with a consultancy company, university, or management college, and usually involved much emphasis on leading and developing people, strategic and innovative thinking, performance management and personal impact, making great use of e-learning, coaching and mentoring, secondments and attachments.

A review of how to create a leadership development programme in US public services also shows a strong emphasis on such 'intrapersonal' qualities, and what we have termed 'leader development' (Pernick, 2001). Essential tasks included creating programme selection criteria (making sure to include personality traits such as desire, purposefulness and confidence), defining leadership competencies, establishing an application process, assessing participants' current leadership skills (using 360 degree feedback, assessment centres and appraisal data), providing developmental activities (building a personal development plan and use coaching and mentoring), aligning structures to reinforce the programme, developing leaders in context, planning for the next generation, and evaluating the programme. A case study of leadership development in San Diego County (Green, 2002) discusses how the agency developed a 'Leadership Academy' involving the identification of talent, use of 360 degree feedback, various psychometric instruments assessing personality and preferences, discussions with the $\mathrm{CEO}$ of the strategic plan, coaching, an action learning project, and the completion of a leadership development journal.

Though clearly fashionable, and perhaps even useful as 'leader development', our view is that 'leadership development' involves attention to more collective and contextual processes. Day (2000) notes that many currently popular leadership 
development practices (like 360 degree feedback, mentoring and action learning) were originally developed and implemented in organisations for other reasons (eg to improve performance management, enhance socialisation, and increase productivity). Perhaps the most popular approaches, following the individualised, competencebased models of leadership discussed earlier, have been based on personal development programmes for developing leaders- what we term 'leader development' as opposed to 'leadership development'. This reinforces the message that leadership is about the personal attributes or competencies of leaders (Boydell, Burgoyne and Pedler, 2004) and that such qualities or attributes can be developed through programmes of personal 'leader development'. Such an approach has been described as 'an alienating social myth' (Gemmil and Oakley, 1997), encouraging learned helplessness among 'followers.'

One way of characterizing the difference between leadership development and leader development is to draw upon the distinction put forward by Dale and Iles (1992: 54) between manager development and management development. They argue that 'management development is generally taken as referring to manager development. It is important to distinguish between the two, as the former can also refer to the processes in which the manager is engaged. Consequently, if an organisation wishes to improve its performance, it needs to find ways of training and developing the groups that manage the organisation collectively.' In their view, 'Management development is used to refer to the development of management processes and the collective skills of those involved in their operation '(Dale and Iles, 1992: 58). They give as examples of management, rather than manager development changes to career development, work allocation, communication channels, and organisational planning processes, and point out that 'all these initiatives require the 
acquisition of skills by the individual managers and changes to the management processes used by the organisation.' Their argument is that both manager and management development are necessary, but should not be conflated.

Given the distinctions between leadership and management discussed earlier, we suggest that leadership development also should not be conflated with leader development. Leadership development involves the development of leadership processes in addition to the development of individual leaders. Day (2000) develops a similar argument about the conceptual confusion between leader development and leadership development from another perspective, relating this distinction to that between human and social capital. He argues that there is a need to link leader development, based on enhancing human capital, and leadership development, based on creating social capital, a concept first developed in community studies to explain neighbourhood survival through personal relationships and collective cooperation (Jacobs, 1961). Leadership development is defined as 'expanding the collective capacity of organizational members to engage effectively in leadership roles and processes' (Day, 2000: 582). Unlike 'leadership competencies', social capital cannot be regarded as a commodity, and one sole actor or 'leader' cannot have 'ownership rights'. Leadership development therefore involves helping people to understand, in an integrative way, how to build relationships to access resources, coordinate activities, develop commitments and build social networks. Leadership roles refer here to those that come with and without formal authority, whilst 'leadership processes are those that generally enable groups of people to work together in meaningful ways' (Day, 2000: 582). In order to do this, leaders need to be encouraged to develop their understanding of themselves and their social and organisational communities and imperatives. Leadership development 'involves building the 
capacity of people to learn their way out of problems that could not have been predicted' (Dixon, 1993), or that arise from the disintegration of traditional organisational structures and the associated loss of sense- making (Weick, 1993).

Whereas most current ' leader development' focuses on skills development and attitude change, with few, if any, connections being made to organisational context or organisational performance, leadership development is oriented to building capacity in anticipation of unforeseen challenges. Rather than see leadership in terms of an individual- level skill, as in transformational leadership theory, and in terms of intrapersonal skills and abilities, this approach involves the analysis of the complex interactions between the 'leader' and the social and organisational environment; leadership is a social process engaging members of a community, with leadership an effect rather than a cause, an emergent property of social interaction in context.

Leadership development therefore involves using social/ relational processes to help build commitments among members of a community of practice (Wenger, 1998), which may be internal and/or external to the organisation. Organisations 'need to attend to both individual leader and collective leadership development' (Day, 2000: 582 ) in order to build leadership capacity. Whilst leader development focuses on individual- level knowledge, skills and abilities and intra-personal competences such as self- awareness and emotional awareness, self- regulation, and self- motivation in building human capital, leadership development focuses on building and using interpersonal competence, including emotional competence and social skills. The focus is on building networked relationships that enhance cooperation and resource exchange and social capital, based on relationships created through interpersonal exchanges (Bourdieu,1986). Nahapiet and Ghoshal (1998) see social capital as having three dimensions: structural (social interactions, assessed by network ties and formed 
by commitments), relational (rooted in networked relationships, such as trust and trustworthiness) and cognitive (resources embodied in shared representations and collective meanings, such as cultures and shared visions based on common values). This focus in leadership development is therefore on the interaction between individuals and social and organisational environments (Fiedler, 1996), involving such considerations as 'how to relate to others, coordinate their efforts, build commitments and develop extended social networks' (Day, 2000: 582). Leadership development is seen as potentially taking place anywhere, involving learning from work in the context of ongoing work initiatives tied to strategic imperatives.

Day (2000) sees the growing use of 360 degree feedback, or multi- source, multi - rater feedback, as having a strong focus on assessment, but being weak on challenge; it may be a valuable developmental tool to build intrapersonal competence in terms of self- knowledge, self- awareness, and trustworthiness, but its primary impact is on building human, not social, capital. Executive coaching is seen as involving the comprehensive integration of assessment, challenge and support, especially if linked to 360 degree assessment, when it can potentially enhance both human and social capital by increasing both weak and strong network ties (Granovetter, 1973) and acting as a link between leader and leadership development. Mentoring, in contrast, is oriented to support, rather than challenge or assessment, and can enhance the cognitive dimensions of social capital (eg more sophisticated strategic representations) as well as the greater mutual trust, respect and commitment dimensions of social capital.

Networking is primarily about investing in and developing social capital, with a primary emphasis on developing support as well as on expanding definitions through exposure to others' thinking and forming commitments outside ones' 
immediate work - group. In this sense, it can build peer relationships across functional areas, leading to the creation of additional social capital, as well as linking leadership development with leader development if used in conjunction with feedback, coaching, and mentoring. Job assignments may help build knowledge and skills in team- building, strategic thinking, and influencing, but may be most effective if jobs with specific development potential are linked to individual development needs through prior assessment. Action learning, whilst providing both challenge and support, may work better for leadership development if formal assessment is used to select action learning project members and structured opportunities for reflection are included; high trust and psychological safety among action learning project team members is likely to enhance the relational and cognitive dimensions of social capital, as well as the structural dimension.

One example of leadership development from an action learning/ social learning perspective is the one- year longitudinal study of 50 Australian R\&D project teams led by 25 new and 25 experienced leaders, based upon the collection of both quantitative and qualitative data (Hirst et al, 2004). The hypothesis was that leaders learn from challenging work, from solving problems, and from team leadership, and use this learning to foster team communication and enhance team performance. The learning of project leadership skills (managing individuals, team management, understanding how the organisation works, dealing with people outside the team, and technical knowledge) was related to facilitative leadership, team reflexivity and team performance. There was a significant impact of the leaders' learning on subsequent facilitative leadership and team performance 8 and 12 months later, suggesting a time lag between learning leadership skills and translating these into leadership behaviour. Most of the new learning, especially for new leaders, concerned how to manage and 
influence social relationships inside and outside the organisation, via such mechanisms as networks, the deployment of negotiation skills, and, generally, through interacting in the political arena of the organisation.

In summary, we have argued for distinguishing leader development from leadership development. Leader development refers to developing individual- level intrapersonal competencies and human capital (cognitive, emotional, and selfawareness skills for example), whilst leadership development refers to the development of collective leadership processes and social capital in the organisation and beyond, involving relationships, networking, trust, and commitments, as well as an appreciation of the social and political context and its implications for leadership styles and actions. As Hirst et al (2004:324) argue:

organisations should place greater emphasis on experiential learning so as to foster sustained behavioural and practice changes. Organisations can introduce formal mentoring and job rotation programs, 'stretch assignments,' and opportunities for more senior responsibilities to build the experience base. These activities have been found to be powerful stimulants of experiential learning.

Hirst et al (2004) suggest that as the learning of leadership takes time to be operationalized, leadership development programmes should be continuous and ongoing, rather than single events with no follow-up.

The mode of leadership development under consideration in the present paper reflects this more nuanced social, contextual, networked and distributed view of leadership. How effective it is in encouraging self- understanding and an understanding of social and organisational contexts, and in helping to build/enhance 
relationships and networks, coordinate actions and develop commitments is the subject of the following sections.

\section{THE ACADEMY FOR CHIEF EXECUTIVES, NORTH EAST AND TEESSIDE BUSINESS SCHOOL RESEARCH PROJECT}

The Business School at the University of Teesside and The Academy for Chief Executives (ACE), North East (ACE/NE) collaborated on a project focussed upon the development of present and future executives and senior managers in the north east of England. The project ran between the beginning of July, 2002 and the end of June, 2004. The objective was:

To assist the Region's economic and social development through the spread of effective leadership, learning and best practice within North East businesses and hence to benefit the community as a whole (News Release, 31/1/03).

This was to be achieved through three main means:

1. The inauguration and development of 'New Leaders' Forums', intended to 'spread business learning and good practice among managers who are potential future leaders [and] also the heads of small companies' (News Release, 31/1/03)

2. The further development of the existing ACE/NE Group, and

3. A research and evaluation project carried out by Teesside Business School as part of the main project.

An explicit link was made in the above news release and in the original funding application to the regional economic strategy of One North East (the relevant Regional Development Agency), where the latter calls for 'leadership excellence 
among current leaders and developing leadership among emerging leaders', and the release adds 'The programme will help to realise this goal through peer-group learning, entrepreneurship and high-level skills development anchored in best practice'.

The Academy for Chief Executives is organized around a geographically-based group network covering the UK, with a central office in Letchworth, Herts. As a matter of policy, groups are kept to a small size, with a maximum of around fourteen members. Membership is ‘by invitation' only, but recruitment drives are held throughout the year. Each group Chairman ensures that its members' organizations are not in competition with each other, in order to help ensure a 'full and frank' exchange of views. Meetings are held once a month, organized and run by the local group Chair(s), and are rotated around the members' premises. They last for a whole day, and usually consist of a 'speaker session' in the morning followed by an 'issues' session in the afternoon, and one-to-one coaching sessions between the Chairs and members at the end of the day if these have been previously booked (or at other times as appropriate). The speaker sessions last for around three to three and a half hours, and cover a range of topics over the year, such as business strategy, marketing, using the media, motivation, change, and finance. Not surprisingly, they tend to be highly interactive. Following a break for lunch, the issues session involves members outlining the particular matter they wish to discuss to the rest of the group, providing clarification, taking questions, and then hearing the views and suggestions of the members and Chair(s). Everyone involved is sworn to secrecy, and the discussion is tape-recorded by the Chair, who hands the tape over to the member concerned at the end of his/her part of the issue session. The one-to-one coaching sessions attract an extra charge on top of the monthly membership fee, and members tend to use them 
occasionally on a 'perceived need' basis; they are often held on the member's premises. Once a year each Group also holds a 'Retreat', which is residential and normally lasts for two full days, thus facilitating more extended discussions and presentations, as well as the opportunity to mix socially and incorporate leisure interests/pursuits, such as hill walking, golf and tennis.

The ACE central office runs an extranet for the members, which, inter alia, posts notices of forthcoming meetings and events, incorporates a discussion forum, lists details of members and approved Academy presenters, and provides details of and access to business/management articles. Regular 'national' seminars are held during the year, for example in 2003 a consultant ran two 'family business' seminars for the Academy, and a 'High Performance Coaching' seminar was run at a variety of venues throughout the UK. The Academy also organises and runs an annual 'Leaders' Quest' abroad-countries visited have included China, India and South Africa. The following extracts from ACE publicity material provide illustrations of the nature and orientation of the Academy:

Our Purpose is to "nurture an environment which inspires leaders to achieve their extraordinary potential'.

If you, as the most influential person in your organisation, can't find the time to develop and hone your own skills, then what is the likely long term risk to you and your company going to be? Chief Executives are often the last person within a company to seek out ongoing development. However, you are an important role model who needs to demonstrate the value of continuous learning and in turn reflect this behaviour in your organisation. Some of our 
members tell us that their membership is of far greater value than the cost of a non-executive director; in fact they think of their fellow group members as a phenomenal resource that they can tap into whenever they wish.

In the $\mathrm{ACE} / \mathrm{NE}$ region, a 'Chief Executives' group has been in existence for some time, and the ten to twelve or so members of this Group are all experienced chief or senior executives of local organizations. In addition, a 'Leaders' Forum' (LF) group was formed during the second half of 2002, as a result of the ACE/NE and University of Teesside Business School securing ESF funding for the project; this made possible, inter alia, a discounted level of subscription for the LF group. LF members are, in essence, people who, whilst in senior positions in their organizations, have not yet reached the top positions attained by the main Members' Group; putting it another way, they are seen as 'tomorrow's top executives/leaders'. The LF group has similar objectives to the Members' Group, but the two groups are run separately and in parallel, with the anticipation that LF members will, in time, and given their own career progression, transfer into the Members' Group. For both groups, a key objective of ACE membership is that the learning and development gained through meetings, issues sessions, etc, is disseminated through their organizations, such that a range of staff benefit and 'organizational learning' occurs. Members are periodically reminded of this wider objective by the Branch Chairman during the monthly meetings.

\section{METHODOLOGY}

Three methods of data collection have been adopted for the research and evaluation aspect of the project: interviews, documentary analysis, and participant observation. 


\section{Interviews}

All members of both the Chief Executives and LF groups in the ACE/NE region have been individually interviewed by the authors. The focus was upon why they joined the ACE, their experience of, and reflections upon, the Academy (both locally and nationally), the learning which they believe has occurred and its transfer into their organizations, etc. An interview pro forma was employed, and anonymity was, of course, guaranteed. With the permission of the participants, the interviews were taperecorded and subsequently transcribed and content analysed (permission was not granted in only one case, when notes were taken in lieu). In total, this has amounted to some twenty interviews, conducted at the member's place of work, and lasting between one and two-and-a-half hours.

The interview programme began in October, 2003, and was completed in October, 2004, with the LF interviews taking place between March and October 2004 in order to ensure that the people concerned had been members of the ACE for at least six months. The findings reported upon here are, in the main, based upon the Chief Executives' group interviews.

\section{Documentary analysis}

One of the authors was made an 'Honorary Member' of the ACE early in 2003, and therefore had access to the extranet and literature produced by both the ACE/NE and the national office, as well as to some 'internal' documents of ACE/NE. For reasons of confidentiality, much of this data cannot be reproduced or referred to in the paper, but it has nonetheless informed our reflections and findings. 


\section{Participant observation}

Because of the honorary membership, one of the authors was able to attend and take part in the Chief Executives' group monthly meetings, that is the speaker session in the morning and the issues session in the afternoon. Hand-written notes were made during the speaker sessions, including of the questions asked and comments offered by the members and Chairman. Attending the meetings proved invaluable in getting to better know the members, their work and personal interests, concerns and orientations. Lunch and coffee breaks also provided useful opportunities here.

The findings reported upon and discussed below, then, draw upon the first round of interviews (with the Chief Executives' group), documentary analysis and participant observation.

\section{BENEFITING FROM ACE MEMBERSHIP: LEADERSHIP DEVELOPMENT THROUGH BONDING, BRIDGING AND BROKERING}

In the earlier 'Leader Development and Leadership Development' section, where in particular we drew upon the work of Day (2000), we defined and differentiated human and social capital and linked them, respectively, to leader and leadership development. Our data shows that membership participation in The Academy for Chief Executives/NE facilitates leadership development through the development of social capital, and it is to an outline and discussion of how this occurs that we now turn. Before doing so, however, it is important to make a distinction, drawing upon Davidsson and Honig (2003), between two complementary forms of social capital: 'bonding' and 'bridging'. As Jones (2005) has observed 'Bonding social capital, typical of closed networks, describes close intra-organizational relationships based on 
mutual trust and reciprocity. Bridging social capital, typical of open networks containing structural holes, describes inter-organizational links which provide access to new resources and information'. There are a number of examples of both forms of social capital, as well as of brokering, to be found in our ACE data, to which we now turn.

\section{Bonding}

\section{Gaining and bolstering confidence}

The group is the main, and in some cases it would seem, only (one member said at interview 'There is no other group that can do that for most of us') source of advice and support for the members in organizational situations where they are uncertain as to what decision(s) and action to take, and where they feel unable or reluctant to articulate this uncertainty to anyone in their own companies. They do not wish to externalise this felt uncertainty and indeterminacy within their organizations, for that would be to reveal openly that they are not omniscient and so 'sure-footed' as they wish to appear. In the ACE group they have people who a) are at a similar level to themselves in their own organizations, b) have a good deal of business knowledge and experience, and c) they feel they can trust- who will, for example, not divulge what they have said/revealed about themselves and their organization. The interview extracts below from three members are indicative:

Running your own business can at times be quite lonely. It's a family business, and you have the staff and everything, but in terms of sharing things with people and getting advice, it's not easy. And I was quite turned on with 
this, of having this bunch of people where you could share your worries and concerns with and get some help and advice- that has got to have value.

Of course, people in positions like this don't have anyone they can talk to... you can't talk to your colleagues because there might be issues that affect the business, or personal issues you don't want to discuss, so it's a good forum, and for the business they act as non exec's. In effect you put a business problem to them. Because of their wealth of different experience...they are very, very different people in that group, and that is a strength as well. You have all different sorts of perspectives - it doesn't always give you the answer but it makes you think.

Well it helps your self confidence as well, because when things are not quite going the way you would like them to you start to question yourself, and there is quite a strong self support or group support mechanism that just reminds you of what you have done so far ... so it gives you more confidence. And helping you to think about what you might want to do and to explore some of the things with people from a personal point of view - you might go in a different direction completely - you can explore that with the group and get them to help.

Whilst the goodwill and bonding within the group can be drawn upon to provide advice and to help generate confidence with respect to organizational decision-making and action, some at least of the members were also using this for personal reasons, including with respect to their next job move. Take the example of a plant manager 
who at the time of interview was experiencing uncertainties about his current job because of an imminent head office restructuring of some of the divisions of the company:

You've got some better basis for doing it, and secondly opportunities personal opportunities - and that of course works both ways. The point about networks is that there is an arrowhead on both ends of the line, so what you are looking for, the ideal situation, is of mutual benefit. So, really, it's both the business and the personal, and to be honest its for me more of a personal than the business.

The second example below is taken from an interview with a younger executive heading up a one-location organization with around ninety employees: 'I tend to use the one-to-ones more as a personal type thing in terms of where would I go to next from here'.

The group also functions to bolster the self confidence of these executives and senior managers at times when it is under threat:

Well it helps your self confidence as well, because when things are not quite going the way you would like them to, you start to question yourself, and there is quite a strong group support mechanism that just reminds you of what you have done so far... and helping you to think about what you might want to do and to explore some of the things with people from a personal point of view might go in a different direction completely. 
As well as ACE membership acting to facilitate the establishment and maintenance of self-confidence in the $\mathrm{CE}$ or equivalent role, and once members have come to trust the rest of the group and the Chair, social capital is also developed through learning about each other from each other.

\section{Trust, knowledge and learning}

Once they have been in the Academy for some time, and have come to trust the other members (and be trusted by them), they find it helpful to raise matters of concern during the monthly 'issues' sessions, and also to contact the other members or the Chair directly- for example, over the telephone. Along with the speaker sessions, this alerted them to the variety of perspectives which are adopted on the world of work and organizations:

I think that it has given me another sort of drive, another set of views altogether, a new set of people, completely different outlook on their life and their business, and that is refreshing. I am very conscious that you can get into a blinkered 'Well, this is my world'...it's stimulating.

Tacit knowledge was being exchanged amongst the ACE/NE members in this context of strong ties and trusting relationships (Galunic and Moran, 2000): 'The driver for that [joining the Academy] was the thoughts that you had a group of supportive people there, you could use as a sounding board, and you could continue the learning'. But, of course, it takes time for a sufficient degree of trust to be generated, and, for some people at least, the concern not to lose face in front of the group can 
make it difficult to be open about one's uncertainties and (possible) lack of knowledge:

you go into these things, and certainly in the back of my mind from a personal perspective, I'm not entirely sure what to do, what I ought to do next, what I ought to do in the first place, and what do I want to do afterwards, so you don't say anything, 'cause that's stupid... and somebody said it, and everybody else said 'Actually, we all feel like that', so you start to explore these things, and that is a great help.

For those who are new to the group, or those who are unwilling or unable to articulate some issues or concerns in front of the group, there are other mechanisms available within the Academy structure, such as the 'one-to-one' sessions at their place of work: 'you might not want to talk openly in a group, but you might want to use their coaching skills or ask their advice'. With some of the members it can be particularly difficult, if not impossible, to separate out the 'business' concerns and interests from 'personal/career' ones, as the two are intertwined through their having an ownership interest in the business. Either way, members found the 'personal' and the 'organizational' closely interrelated:

It's as much about the personal level as the business level... if you are an entrepreneur and you start running your own business, then those two are even more closely linked. Now, a lot of people in the group are like that. But I am not, but even so it's been helping me personally and from a business point of view, and they are always linked, of course, quite closely. 
The 'personal' level manifests itself in other ways, too, such as with respect to how the role of CE might/should be acted out, and this can be particularly problematic for new(ish) CEs, as illustrated below.

\section{Role models and support for entry-level CEs/senior managers}

For those members who have recently moved into a chief executive or senior management position, the confidential group advice and support provided through the cohesive network of the Academy can be particularly valuable:

There is no right way or wrong way to do the job, there is no formal training that I am aware of. So it was really to check how other people set about this job and what it is that I have to do- what can I learn...

Such people were uncertain about the nature, demands and expectations of the role they had moved into, and the interaction with experienced practitioners in the Academy provided them with an opportunity in a non-threatening context to gauge how they were performing the CE role and whether this was 'appropriate':

Hopes and expectations from being a relevantly new director as such, I probably had this vision that maybe I was missing something, maybe there was something else out there, and that there was a particular guru style, as it were, of directors that should be doing a particular different thing. Possibly a little bit I had sort of self-belief in my own abilities, but didn't know how that related to other people in the field as it were. I had a view that I could go along and learn from some more of some more experienced people who had 
different experiences to myself... seeing what else is out there and what other people's experiences are and whether I am doing the right thing. It is one of those self- checking things, am I actually doing what I should be doing?

These senior managers, then, were using the Academy sessions as a means of facilitating self-evaluation, comparison and reflection, and recognised that, as the following interviewees put it, 'people skills' is a key ingredient of the role, as is being able to take the lead in 'moving the company forward':

[the meetings] reassured me that it was down to people skills and determination and the will to succeed...coupled with common sense... it is a safe environment where you can actually question yourself and actually say "Well, OK, am I that good, am I in the right job, am I capable of carrying this off?” ... am I holding my company back, am I driving my company forward? It was all those sort of things that you won't want to say in front of your peers, that you could explore, explore it yourself in that environment and just see what is going on.

....and you start looking at these people and going "OK, well he is in a particular mould- if he did it the other way, the stereotypical way with the pinstripe suit and the suave and the polish, would he be any better or worse at what he does?" They were sort of questions that I was looking at and seeing; what it really gave me is the confidence in myself that I am what I am...sometimes you wonder "Well, OK, if I went and got a Masters, would that give me that edge? If I went and changed my accent and, you know, got a 
posh accent, is that what people are looking for in a Chief Executive?" It is, you know, questions, questions, questions- so that is what I got from it.

Finally, with regard to the bonding variety of social capital, it was noticeable that a certain amount of network closure was to be found between the members in the group.

\section{Intra-group network closure}

There were indications in our analysis of our primary data that a degree of network closure was to be found in the group. This had resulted from a number of contributory factors, including the small(ish) size of the group, the long continuity of membership and regular attendance of some people, the membership-acceptance process in which the Chair ensured that there are no competing organizations, and the recognition (as discussed earlier) that this is a unique forum for sharing ideas and knowledge and building and extending commitments. As one of the original members commented:

It's quite a strong cohesive group- we are almost at the point where we can almost say anything to each other and we won't take it the wrong way. It will be constructive, we might not like what we hear, but it will be constructive. People in positions like this don't have anyone they can talk to...you can't talk to your colleagues because there might be issues that affect the business, or personal issues you don't want to discuss... so it's a good forum, and for the business they act as non- exec's in effect. 
It is worth adding, however, that, to the extent that network closure can be said to have taken place in the group, there was a recognition amongst members that this had its drawbacks as well as its advantages, captured nicely in the following observation:

The advantage of having the same small group is that you get to know each other and people relax and things become a lot more informal, and people become a lot more open...[but] there is a significant disadvantage in that you lack then the stimulus of new people with new experiences...I think the danger is the same old faces every month with the same issues.

\section{Bridging and brokering}

In addition to $\mathrm{ACE} / \mathrm{NE}$ membership participation promoting the development of bonding social capital and, hence, leadership, we also found that forms of bridging and brokering social capital were promoting learning and development, in particular through members' exposure to new information, people and organizations. Members recognized the value of being exposed to new/different perspectives on business matters through the speaker sessions, with the added benefit of the speakers coming 'recommended':

opportunity...to find somebody who is an expert in a particular field... you are able ...to maybe get a different perspective on an issue or a problem or more comfortable, instead of going through a list of people you have never even heard of ...you feel as if it were a sort of like a recommendation in a way. 
I think the Academy have actually given us a taste of, once you start to look outward you begin to realize that maybe there is more to be achieved.

Membership of the Academy can also be of benefit in terms of meeting people who can broker new contacts in influential places, thus helping to extend organizational and personal networks. This occurs through both the invited speakers and the other members, some of whom already hold regional positions of influence, and are only too pleased to facilitate 'introductions':

We did have access to [Y] of One North East [the Regional Development Agency]. When Y came to see us he spent about two hours with us [at a monthly ACE meeting], which was brought about by one of the members [who] is on the One North East Board...I made Y aware of construction issues [his company's business] and I got a phone call from Y, and I went to see him, who is also one of me colleagues from the Civil Engineering Association...

It has proved extremely helpful on another level, and that is networking... and you have got people who have a very strong set of contacts, and for me and partly through $\mathrm{G}$ [the ACE/NE Chairman] I was able to get contacts in various groups, associations that I would not have been able to do.

The ACE/NE Branch Chair also on occasions actively created direct access into influential networks, as can be gleaned from the following comment of a member:

...certain things exposed us to different levels, and I must say on that one mainly via $\mathrm{X}$ [Branch Chair] in sort of the diplomatic circles, as it were, that 
... is a whole different process that really you didn't know a lot about unless you were part of it, so we went to the Consulate Ball and met various people from there, and what was reassuring is that they just have different experiences. So from my point of view it was very reassuring....in that I didn't know how good or bad I was... as a benchmark from other people that was fine.

'Reassurance' for members can take on at least one other form, too, and this relates to organizational knowledge and action (the speaker sessions are particularly helpful here):

...what I get out of it [ACE membership] more is maybe reassurance if you like. You put your issues to people and it reassures you that you are going down the right path...'Yeah, that is what you should be doing- that is the way of tackling it".

Some of the issues you can think "Yeah, well I did have some of that issue and that's right", and basically you think "God, other people are in the same position as what I am in". Which is more reassuring.

The issues sessions can be a useful source of help and advice when a member is experiencing difficult times:

I got more benefit when I really had an issue. I wasn't actually doing the oneto- ones, but I really did have an issue. I came to an ugly patch where I was having a big fall out with another executive director- we were into a email situation and I was really up against it, and I was worried which way do I go. 
The following interview extract further illustrates the networking opportunities provided by group membership, and also the way in which the group had begun to act collectively and proactively within the region in an attempt to influence regional policy and practices. Putting this another way, it had identified some regional 'structural holes' and had ideas as to how these might be filled:

It [ACE membership] has proved extremely helpful...on an entirely different level- and that is networking. I have an immense level of frustration about the way the business support and network works- or rather doesn't work- in the North East, and the group...is highly critical, highly critical... and one thing you have got in that group, you have got people who have a very strong set of contacts, and I was able to get contacts in various groups, associations that I would not have been able to do (I know that 'cause I tried). We have even started doing it as a group now, so the group itself will want to meet up with other people and make their views known as well as the individual members. It's almost started acting as an entity on its own... They happen to know somebody- if it isn't the correct contact, it's a very good facilitator for the contact that you do need, and the conventional method of ringing up and trying to speak to somebody doesn't work.

In some instances it is difficult, if not impossible, to tell whether these CEs/senior managers, in creating and pursuing networking opportunities, are attempting to further the interests of the organization for which they currently work, and/or their own career interest as this might develop within or outside their present organization. Of course, for some of them the two are synonymous, for they are full or part-owners of 
the organization for which they work. One member used a specific element of his ACE membership for helping to further his career objectives: 'I tend to use the oneto-one sessions more as a personal- type thing in terms of where would I go to next from here- a personal career'.

\section{CONCLUSION}

Storey (2004) has pointed to the enormous growth of literature on leadership in recent years, whilst at the same time there has been a slower rate of growth in the leadership development literature. He also notes the recent high- profile initiatives on leadership in the UK public sector (eg Cabinet Office 2000; the National College for School Leadership; a new Leadership Centre for the Health Service; new leadership initiatives in the police service and the Ministry of Defence), along with the publication of a variety of reports (eg Horne and Stedman-Jones, 2001). As he observes, typically leadership here is under- specified, seen as a panacea, standing in 'for all the qualities that are desirable in a top team or responsible post-holder' (2004: 5), and assumed to be the answer to a whole range of complex problems, including increasing organisational uncertainty, increasing ambiguity and competitiveness, all of which demand organisational change. Improved/enhanced organisational leadership is seen as the appropriate response, in all sectors.

What is more, as Storey (2004) and ourselves have noted, what is seen to constitute 'leadership' has also changed over time. Prior to the 1980s, 'leadership' and 'management' were rarely differentiated, usually being seen as interchangeable or overlapping activities. Where leadership was differentiated, it was seen as involving influence processes in small groups by supervisors or first-line managers, and was 
typically studied by psychologists using survey or experimental methods. During the 1980s we got 'new paradigm' models such as the 'charismatic' and 'visionary' models of Bennis and Nanus (1985) and the 'transformational' model of Bass (1985), where leadership was linked more closely with the facilitation of organisational change and transformation by senior leaders, not managers. In recent years there has been a further shift: post-Enron, there is much more concern with integrity (Mangham, 2004), with context (Ray et al, 2004) and with 'leadership competences' (Salaman, 2004).

Notwithstanding all the research on 'leadership' and advocacy of 'leadership development', it is noteworthy that, according to a recent Work Foundation study (2003, cited in Storey, 2004: 7), those in top positions in organisations are less likely to receive leadership coaching and tutoring than their junior colleagues (but they nevertheless still espouse the value of leadership). On this reckoning, the leadership development activity experienced by members of the Academy for Chief Executives is an exception to the rule. As regards the wider UK population of Chief Executives, we simply do not know whether this lack of leadership development is due to a lack of awareness and/or time, opportunity, or inclination.

For our interviewees, the opportunities provided for networking, both in relation to their present jobs and possible future jobs, and access to external sources of funding and advice, were important benefits of membership. These opportunities are of both an intra and extra-organisational nature: 'intra' in terms of relating to the 'here-and-now' of organisational policies and practices, and 'extra' in at least two main senses, that is, firstly, through extending their organisation's network of contacts, sources of advice, information, support and intelligence, and, secondly, through extending their own, more personal networks, which they would then be able 
to draw upon in order to further their careers or carve out new careers in different sectors of the economy. A 'career move' may, of course, come about voluntarily, or, on the other hand, through force majeure (as was indeed the case with one of our interviewees). Thus, the social capital formation was both a 'public' and a 'private' good, through providing both organizational and individual benefits.

The adoption of a 'social capital' lense, and the associated focus on bonding, bridging and brokering, as key leadership processes and key dimensions of leadership development, points to links with emerging research on the potential influence of intermediaries and the importance of 'in-betweenness'. For Callon (1997: 134), an intermediary is 'anything passing between actors which defines the relationship between them'. The growth of intermediation may be situated within the context of the 'networked society' (Castells, 1996) or 'splintering urbanism' (Graham and Marvin, 2001). Examples of intermediaries include the role of technology translators as 'knowledge intermediaries' 'in-between' SMEs and universities (Iles and Yolles, 2002), 'market intermediaries', such as market research agencies 'in-between' production and consumption (Cronin, 2004); and town centre managers as 'planning intermediaries' facilitating private-public sector involvement (Paddison, 2003).

Intermediaries are not necessarily individuals, nor necessarily 'neutral': they may seek to bridge and align (Iles and Yolles, 2002; Paddison, 2003), yet have vested interests (such as advertising agencies promoting themselves as indispensable intermediaries between producers and consumers by establishing the currency of their skills or expertise; see, eg, Cronin, 2004) or strategic intermediaries in the water industry who seek to shape practices and translate agendas (see, eg, Medd and Marvin, 2004). Intermediary space is a dynamic, contested space, with intermediaries often filling a gap or deficit within existing relationships. Such gaps may be due to 
professional fragmentation associated with boundary maintenance, or market or governance failure. Intermediaries may then seek to play a transformative role by reconfiguring the relations in which they work, enabling innovation through problemsolving activities and the legitimisation of certain information (SURF, 2005).

Leadership development platforms such as ACE can thus be seen to be acting as intermediaries: facilitating bonding, bridging and brokering activities and claiming legitimacy as transformers of the space between 'leaders' and other networks and institutions. They broker by facilitating communication between actors, coordinating activities, creating and disseminating knowledge, and, in general, providing education and training. They also bridge different forms of provision through 'facework', emotional labour and the development of trust through 'displays of reassurance' (Allen, 2003), and help to bond by aligning interests, analysing needs, and managing third-party relationships and interfaces. They promote stakeholder learning and provide a platform for learning and experimentation, strengthening trust through the alignment of interests and the development of relationships.

To conclude, it can be noted that the perspective on leadership development which we have developed and presented in this paper raises a number of further research questions/issues, including: the 'neutrality' (or otherwise) of such intermediaries and the power relations into which they are enlisted; how they engage with the intermediary space- promoting change, innovation and the reconfiguring of boundaries, or acting to maintain the status quo and preserve professional, institutional or disciplinary boundaries. Furthermore, whose interests does such transformation serve? Are intermediaries such as ACE the product of a gap or deficit? How do they actively shape the space in which they work? How do they compete with 
other leadership development intermediaries, such as consultancies and universities, within and for such a space, and in which contexts?

\section{ACKNOWLEDGEMENTS}

We would like to thank Ossie Jones and the journal reviewers for their most helpful comments on earlier drafts of the paper.

\section{REFERENCES}

Alimo-Metcalfe, B. \& Alban-Metcalfe, R. (2001) The development of a new

Transformational Leadership Questionnaire, Journal of Occupational and Organizational Psychology 74 (1), 1-28.

Allen, C. (2003) On the logic of 'new' welfare practice: An ethnographic case study of the 'new welfare intermediaries, Sociological Research Online 8 (1).

Alvesson, M. and Deetz, S. (2000) Doing critical Management Research, London: Sage.

Alvesson, M. and Sveningsson, S. (2003) Good Visions, bad micro-management and ugly ambiguity: contradictions of (non-) leadership in a knowledge- intensive organization, Organization Studies 24 (6), 961-988.

Antonacopolou, E. \& Bento, R. (2004) Methods of "learning leadership": taught and experiential, in J. Storey (ed) Leadership in Organizations: Current Issues and Key Trends, pp. 81-102. London: Routledge.

Bass, B. (1985) Leadership and Performance Beyond Expectations. Cambridge, MA: Harvard University Press.

Bass, B. (1990) Bass and Stodgill's Handbook of Leadership. New York: Free Press. 
Bass, B. \& Avolio, B. (1993) Transformational leadership; a response to critics, in M. Chemers \& R. Ayman (Eds) Leadership Theory and Research: Perspectives and directions. San Diego: Academic Press.

Bennis, W. \& Nanus, R. (1985) Leaders: their strategies for taking charge. New York: Harper and Row.

Blake, R. \& Mouton, J. (1985) The New Managerial Grid, 3rd Ed., Houston, Texas: Gulf Publishing.

Bourdieu, P. (1986) The forms of capital, in J. Richardson (ed) Handbook for Theory and Research for the Sociology of Education, pp. 241-258. New York: Greenwood. Boydell, T., Burgoyne, J. and Pedler, M. (2004) Suggested Development. People Management 10 (4), 32-34.

Burns, J. (1978) Leadership. New York: Harper and Row.

Cabinet Office (2000) Strengthening Leadership in the Public Sector: A research Study by the PIU. London: Performance and Innovation Unit.

Callon, M. (1997) Techno-economic networks and Irreversibility: in Law, J. (ed) A Sociology of Monsters: Essays on Power, Technology and Domination. London: Routledge.

Castells, M. (1996) The Information Age: Economy, Society and Culture. Vol 1: The rise of the Networked Society. Cambridge, MA: Blackwell Publishers.

Cronin, A. (2004) Regimes of Mediation: advertising practitioners as cultural intermediaries. Consumption, Markets and Culture 7 (4).

Dale, M. \& Iles, P. (1992) Assessing Management Skills : a guide to competencies and evaluation techniques. London: Kogan Page.

Davidsson, P. and Honig, H. (2003) The Role of Social and Human Capital Among Nascent Entrepreneurs, Journal of Business Venturing, 18:2: 310-31. 
Day, D. (2000) Leadership development: a review in context, Leadership Quarterly, $11(4), 581-611$.

Dixon, N. (1993) Developing managers for the learning organization, Human Resource Management Review 3, 243-254.

Doos, M. and Wilhemson, L. (2003) Work Processes of shared leadership. Paper presented to British Academy of Management Annual Conference.

Drath, W. and Palus, C. (1994) Making common sense: leadership as meaningmaking in a community of practice. Greensboro, North Carolina: Center for Creative Dulewicz, S. \& Higgs, M. (2000) Emotional Intelligence: the key to future successful corporate leadership? Journal of General Management 25 (3),1-14.

Dulewicz, S. \& Higgs, M. (2000) Emotional Intelligence: A review and Evaluation Study, Journal of Managerial Psychology 15 (4), 341-368.

Dulewicz, S. \& Higgs, M. (2004) A new instrument to assess leadership dimensions and styles, Selection and Development Review 20 (2), 7-12.

Dulewicz, S. \& Higgs, M. (2005) Assessing leadership styles and organisational context, Journal of Managerial Psychology 20 (1/2), 105-123.

Ehrich, L., Cranston, N. and Kimber, M. (2005) Muddling through ethical dilemmas for educational leaders: towards an exploratory model. Paper presented to British Academy of Management Annual Conference.

Fiedler, F. (1967) A theory of leadership effectiveness. New York: McGraw Hill. Fiedler, F. (1996) Research on leadership selection and training: one view of the future, Administrative Science Quarterly 41, 241-250.

Galunic, C. and Moran, P. (2000) 'Social Capital and Productive Exchange: Structural and Relational Embeddedness and Managerial Performance Link'. Insead Working Paper, 2000/07/OB. 
Gemmil, G. \& Oakley, J. (1997) Leadership: an alienating social myth? in K. Grint (ed.) Leadership. Oxford: Oxford University Press.

Goffee, R. \& Jones, G. (2000) Why should anyone be led by you? Harvard Business Review, September- October, 63-70.

Goleman, D. (1996) Emotional Intelligence. London: Bloomsbury.

Graham, S. and Marvin, S. (2001) Splintering Urbanism: networked infrastructures, technological mobilities and the urban condition. London: Routledge

Granovetter, M. (1973) The Strength of Weak Ties, American Journal of Sociology, $78,1360-1380$.

Green, M. (2002) Ensuring the organisation's future: A leadership development case study. Public Personnel Management, 31(4):31-44.

Grint, K. (2005) Leadership: Limits and Possibilities. Basingstoke: Palgrave Macmillan.

Gronn, P. (1999) Substituting for Leadership: The Neglected Role of the Leadership Couple. Leadership Quarterly 10 (1): 41-62.

Gronn, P. (2002) Distributed Leadership as a Unit of Analysis. Leadership Quarterly 13 (4): 423-451.

Hersey, P. \& Blanchard, K. (1982) Management of Organisational Behavior:

Utilizing Human Resources. Upper Saddle River, NJ: Prentice Hall.

Higgs, M. (2003) Developments in Leadership thinking, Leadership and Organization Development Journal 24 (5), 273-284.

Higgs, M. \& Rowland, D. (2003) Is change changing? An examination of approaches to change and its leadership. Henley Working Paper 0313. Henley: Henley Management College. 
Hirst, G., Mann, L., Bain, P., Pirola-Merlo, A., \& Richver, A. (2004) Learning to lead: the development and testing of a model of leadership learning, The Leadership Quarterly 15, 311-327.

Hogan, R. \& Hogan, J. (2001) Assessing leadership: a view from the dark side, International Journal of Selection and Development 9 (1/2), 40-51.

Horne, M. \& Stedman-Jones, D. (2001) Leadership: The Challenge for All? London: Institute of Management/DTI/DEMOS.

Horner, M. (1997) Leadership Theory: Past, present and Future. Team Performance Management 3 (4):270-287.

House, R. and Aditya, R. (1997) The Social Scientific Study of Leadership: Quo Vadis? Journal of Management 23 (3): 409-473.

IDS (Income Data Services) (2003) Leadership Development. July, No. 753.

Iles, P. and Yolles, M. (2002) Across the Great Divide: HRD, technology translation and knowledge migration in bridging the knowledge gap between SMEs and Universities. Human Resource Development International 5 (1): 23-53.

Inglis, L. and Sarros, J. (2003) Distributed Leadership: A Case Study of an Australian Voluntary NonProfit Organization. Paper presented to Annual Conference, British Academy of Management.

Jacobs, J. (1961) The Death and Life of Great American Cities Jones, O. (2005) Manufacturing Renewal Through Corporate Entrepreneurship: Middle Management and Organizational Innovation, International Journal of Operations and Production Management, 25(5), 491-511.

Kaipiainen, S. (2004) The relationship of emotional intelligence with leadership and self- awareness in predicting organisational outcomes. Unpublished $\mathrm{PhD}$ thesis, University of London. 
Kakabadse, A. and Kakabadse, N. (1999) Essence of Leadership. London: International Business Press.

Kanter, R. (2003) Leaders and the Psychology of Turnarounds. Harvard Business Review June, 81(6).

Kets de Vries, M. \& Florent-Treacy, E. (2002) Global leadership from A to Z: creating high commitment organization. Organization Dynamics, 295-309.

Khatri, N., Harvey, A. and Tirimizi, S. (2001) An alternative model of

Transformational Leadership. Paper presented to British Academy of Management Annual Conference.

Kotter, J. (1990) How Leadership differs from Management. New York: Free Press.

Kotter, J. (1996) Leading Change. Harvard: Harvard Business School Press.

Mangham, I. (2004) Leadership and integrity, in J. Storey (ed) Leadership in

Organizations: Current Issues and Key Trends, pp. 41-57. London: Routledge.

Manocha, R. (2004) Spot the difference, People Management, 10(4), 36-38.

Marvin, S. and Medd, W. (2004) Sustainable infrastructures by proxy?

Intermediation beyond the production-consumption nexus, in Southerton, D.,

Chappells, H. and van Vliet, H. (eds) Sustainable consumption: the implications of changing infrastructures of provision. London: Edward Elgar.

Nahapiet, J. \& Ghoshal, S. (1998) Social capital, intellectual capital and the organisational advantage, Academy of Management Review 23, 242-266.

O'Kane, C. and Cunningham, J. (2005) Strategic Turnarounds and Management Styles of Newly Appointed Leaders. Paper presented to British Academy of Management Annual Conference.

Paddison, A. (2003) Town Centre management (TCM): a case study of Achmore. International Journal of Retail and Distribution Management, 31(12). 
Pernick, R. (2001) Creating a leadership development program: nine essential tasks. Public Personnel Management, 30(4):429- 445.

Ray, T., Clegg, S. \& Gordon, R. (2004) A new look at dispersed leadership: power, knowledge and context, in J. Storey (ed) Leadership in Organizations: Current Issues and Key Trends, pp. 319-36. London: Routledge.

Salaman, G. (2004) Competences of managers, competences of leaders, in J. Storey (ed) Leadership in Organizations: Current Issues and Key Trends, pp. 58-78.

London: Routledge.

Salovey, P. \& Mayer, J. (1990) Emotional Intelligence, Imagination, Cognition and Personality, 9: 185-211.

Sarros, A. and Sarros, J. (2005) The first twelve months: Leadership Challenges of a new CEO. Paper presented to British Academy of Management Annual Conference. Sims, R. (2000) Changing an Organisation's culture under new Leadership. Journal of Business Ethics, 25: 65-78.

Sjostrand, S. and Tyrstrup, M. (2001) Recognised and unrecognised managerial leadership. In S. Sjostrand, J. Sandberg and M. Tyrstrup (eds) Invisible Management: the Social Construction of Leadership. London: Thomson.

Storey, J. (ed.) (2004) Leadership in Organizations: Current Issues and Key Trends. London: Routledge.

SURF (Centre for Sustainable Urban and Regional Futures) (2005). Briefing paper: Researching Inbetweeness. Manchester, September.

Thomson, A., Mabey, C., Storey, J., Gray, C. \& Iles, P. (2000) Changing patterns of management development. Oxford: Blackwell.

Tuckman, B. \& Jensen, M. (1997) Stages of small group development, Group and Organizational Studies 2, 419-27. 
Van der Weide, J. and Wilderom, C. (2001) Leadership Behavior of highly effective middle managers. Paper presented to British Academy of Management Annual Conference.

Weber, M. (1978) Economy \& Society, 2 vols. Los Angeles: University of California Press.

Work Foundation (2003) Developing Leaders. London: Work Foundation.

Yukl, G. (1999) An Evaluation of Conceptual Weaknesses in Transformational and Charismatic Leadership Theories, Leadership Quarterly 10 (2): 285-305. 